\title{
The Wascana Waterfowl Park
}

\author{
FRED LAHRMAN, Regina
}

The Wascano Waterfowl Park established in the Wascana Marsh on the eastern outskirts of Regina city has recently been officially designated a bird sanctuary under the name of the "Wascana Lake Bird Sanctuary." This status allows the exercise of some control, and the Department of Natural Resources provided an enforcement officer to protect the area for the first week of the hunting season in order to inform the public of the project and the boundaries of the preserve. The marsh was also posted, signs like the one pictured on the next page being provided by the Regina Fish and Game League to identify the Wascana Waterfowl Park. Other temporary signs were put up prohibiting motor boats throughout the area and prohibiting fishing near the island's nesting sites. The park still needs a fence and a granary for storing feed.

A marsh is a very specialized type of park, and Regina deserves credit for its effort to utilize and preserve this natural area.

\section{GEESE IN THE WASCANA MARSH}

On April 7, 1953 the first pair of Canada Geese were given Fred Bard by "Hiawatha", Ralph Stueck of Abernethy. The pair, named Hiawatha and Queenie, soon settled down to nesting duties and hatched five young, but owing to our inexperience and to other causes, they succeeded in raising only one.

During the summer this first pair were joined by the "city" geese which had wandered away from Rotary Park. Late in the fall another bird was added to the flock. This bird had been confiscated by a Game Warden who had no place but a R.C.M.P. cell to keep him in for the night. After his night in jail the goose was known as the "Outlaw".

A flock of seven geese were taken to the Perry sanctuary at Govan to spend the winter. On April 12, 1954 the geese were returned to Mr. Bard's sanctuary along with another pair, "Charlie" and "Martha", from the Last Mountain Lake Game Preserve
Goose project. Nine goslings were hatched from two nests that spring, but again misfortune struck. A muskrat robbed a nest of three eggs, a mink killed three goslings, a dog killed another, and two simply disappeared. Three young only were raised to maturity.

On November 14, a Snow Goose with a slightly injured wing was found in the sanctuary with the Canada Geese. It could fly very well but its right wing tip drooped a little while the bird was at rest. It was wary and would fly away when I brought out the feed, but as the days passed it soon swam up to eat along with the Canadas. On Dccember 12 the Snow Goose was missing. Apparently it had resumed its southward migration. Our twelve Canadas, however, spent the winter in the open water near the Power House.

During the spring of 1955 ten goslings were hatched from three nests and nine were raised to maturity. Four more geese were received from the Perry sanctuary. The young goose which was raised in the summer of 1953 had been killed when it flew into a power line.

Twenty-four geese began the winter of 1955. Walter Sweet, Bill Leitch and other Power House employees went out daily during the winter to feed the ge.se and the hundreds of ducks whicis regularly spend the winter on the open water there. During December three geese were found to be missing. Two others, which were found injured, died later. Charlie was one of these.

The spring of 1956 was a hazardous one for the geese. The first nests (with the exception of one) were lost in the spring flood. We salvaged some eggs, but only five of these hatched. The hen that hatched them lost one soon after hatching, but raised the other four to maturity. They are now flying as adults over the Wascana Marsh. The one pair of geese which brought off their young in spite of the flood were lost to vandals who killed the pair and destroyed all the young (continued on page 11\%) 


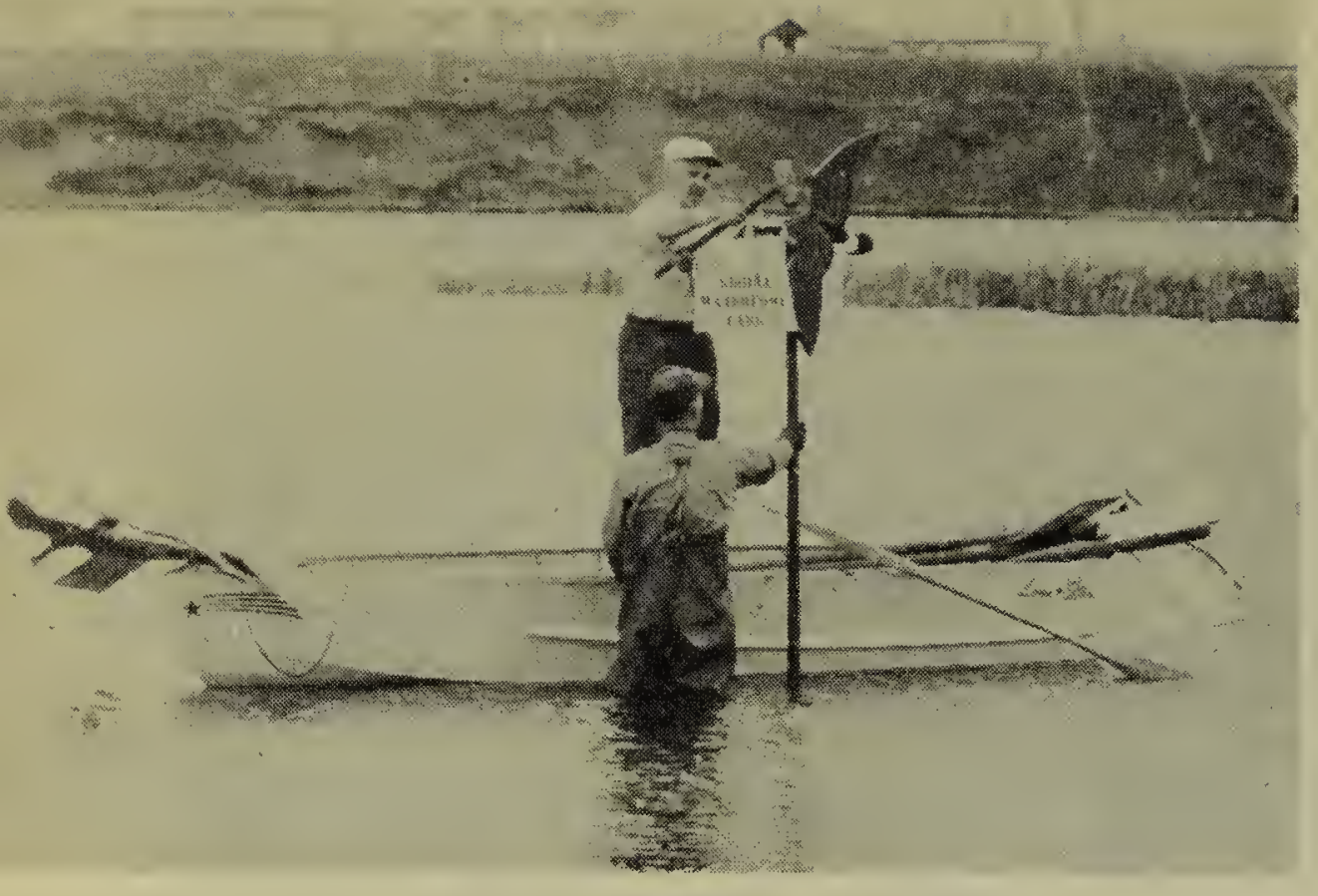

\section{WASCANA LAKE}

Photographs by

In the summer of 1956

the Wascana Marsh was posted with signs provided by the Regina Fish and Game League.

Four Whistling Swans rise in graceful flight from the Wascana Marsh.
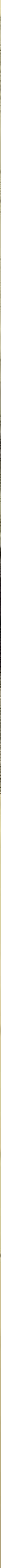

The Waterfowl Park really owes its beginnings to "Hiawatha" \& "Queenie", who came to the sanctuary in '53 


\section{BIRD SANCTUARY}

F. W. Lahrman

Four Canada Geese were raised in 1956 with a hen. They were hatched from eggs salvaged from flooded nests.

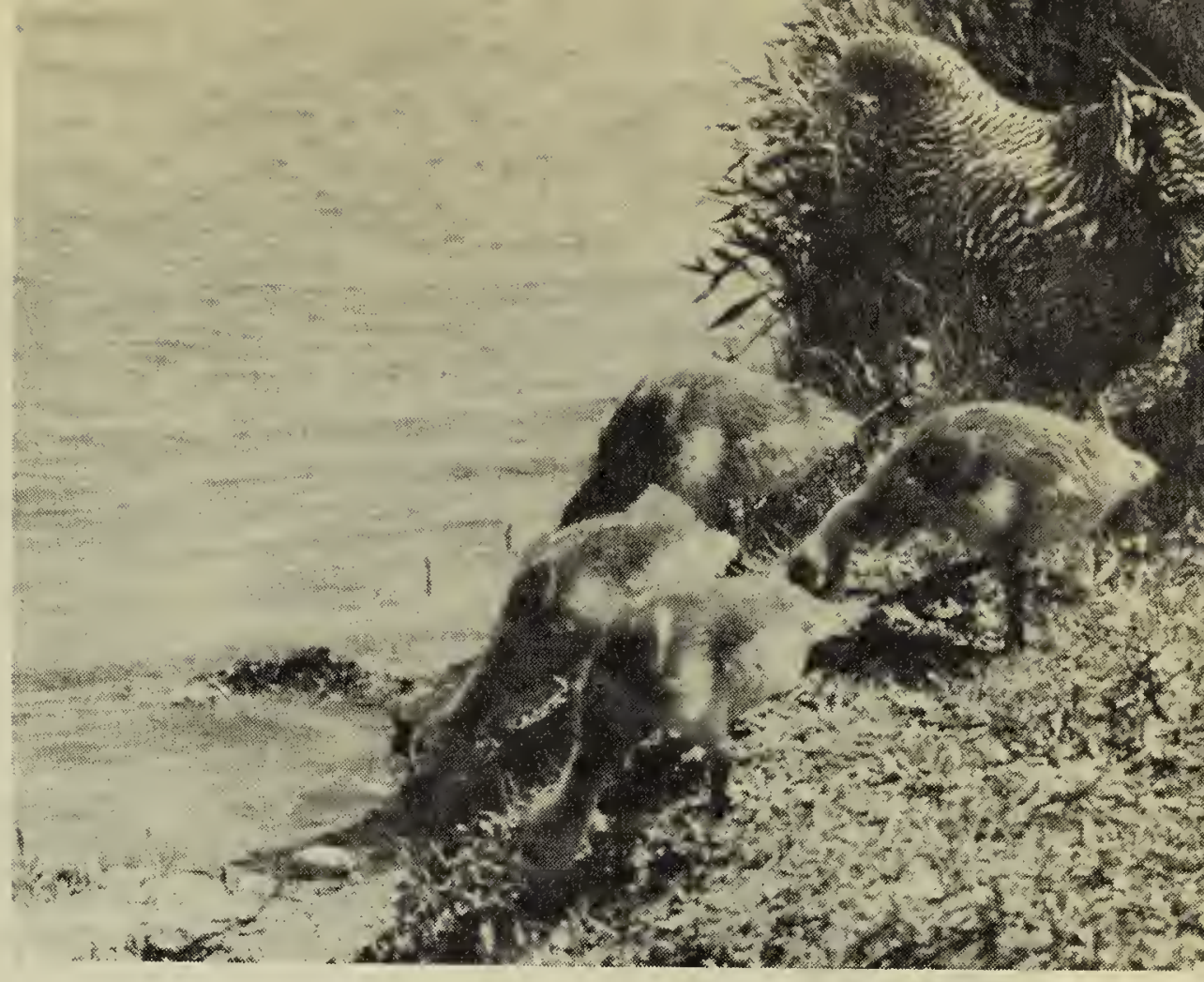

Whistling Swans have wintered at the sanctuary the last two years.

One pair of Geese ("Outlaw" and mate) brought off their young in spite of the 1956 flooding.

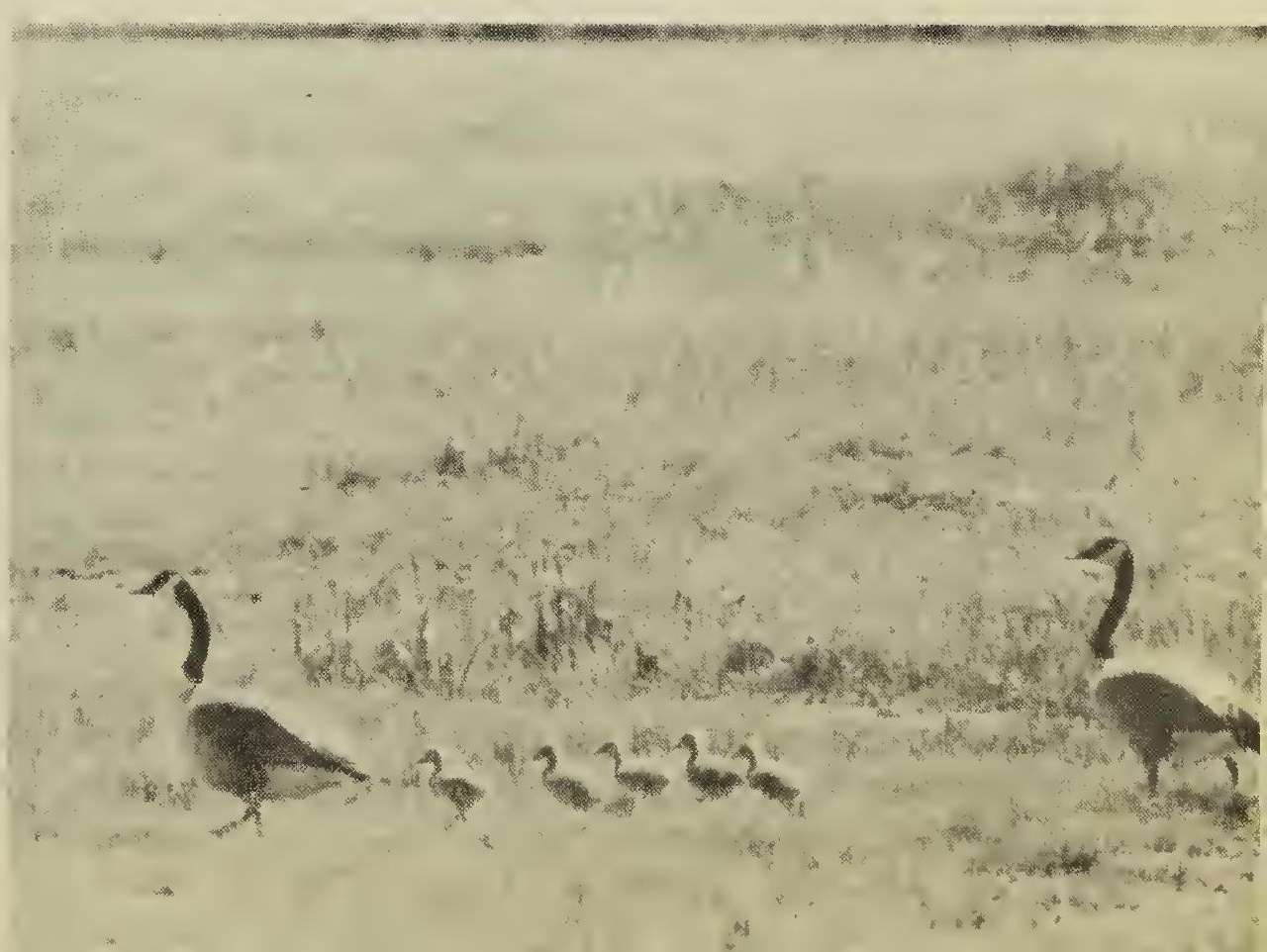


(continued from page 113)

with the exception of one. This gosling joined a gander standing guard near another nest, and he took care of it! The other geese re-nested and in time we had a total of 20 goslings. Since then, we have had no losses. One additional bird was brought in from Lac La Ronge where it had been found wounded. It has been wing-clipped so that it will remain in the sanctuary until it has mated with one of our young birds. Then it will regain its power of flight after next seasons moult. One other bird was brought in by $\mathrm{Mr}$. McLeod, Manager of the Exhibition Board, and was mated within a week of its release in the Wascana Marsh. It was successful in raising a brood. The total population of Canada Geese at the Wascana Lake Bird Sanctuary in early September was 31 . In addition there were seven geese (the young of last year) at large. Interestingly enough, five of these returned on September 19, making a total of 36 .

The majority of the geese at the sanctuary are flying daily for short periods over the marsh area. We operate a rather heavy feeding programme during the hunting season in order to keep them from moving out into the grain fields where they might be shot.

\section{WHISTLING SWANS AT THE SANCTUARY}

On April 26, 1954 two Whistling Swans were found wounded at Lang. Apparently, they had flown into a power line, as each had a broken wing which had to be amputated. These birds were placed in the sanctuary with the geese where they completely regained their health.

On October 15, 1954 another wounded Swan was found in a stubble field eighteen miles south of Regina. This swan was banded and it regained its power of flight during the following summer. It would fly away for the day and return to the sanctuary in the evening, but on September 7, 1955 it flew away and did not return. During December of the same year, one of the Lang swans died from unknown causes.

Since then three more wounded swans have been added to the sanctuary, making a total of four Whistling Swans. One of these is banded and, though able to fly, it has so far chosen to remain with its friends.

At times during the spring and fall migration small flocks of Whistling Swans stop for a day or more on the marsh to join the wounded swans. They and the injured swans that remain all year add a note of interest and of beauty to the quiet waters of this protected area.

\title{
The Caspian Tern in Saskatchewan- with First Nesting Record
}

\author{
By DR. STUART HOUSTON, Yorkton
}

The North American range of the Caspian Tern wras given by Bent as "widely scattered localities, mainly on the coasts or large lakes." These localities ranged from Louisiana and Texas on the south, Oregon and California on the west, Virginia on the east and Labrador and the North West Territories on the north. Although known to occur at Lake Winnipeg and Lake Winnipegosis in Manitoba and the Athabaska Delta in Alberta, it was not listed by Mitchell in his "Birds of Saskatchewan" in 1924. However, three years later Mitchell was able to collect a female Caspian Tern at Old Wives Lake (Lake Johnstone) on
June 28, 1927, and this formed the only known published record of this species for Saskatchewan.

On July 13, 1956, we had the good fortune to locate the first known nesting colony in Saskatchewan, while banding cormorants and pelicans on Rock Island in Dore Lake, 60 miles north of Big River. Our hosts, Zig Kondzielowski and Trigve Larson of the fisheries research unit, called our attention to the large and striking adults overhead and located the small group of 11 young Caspian Terns which we then banded. The tarsi of these young birds barely accommodated the size 5 bands, whereas the Common Tern requires only a much smaller size 3 band. 